Volume 1 Issue 1, January-June 2020: PP: 15-26

Faculty of Law, Universitas Lampung, Bandar Lampung, Indonesia.

http://jurnal.fh.unila.ac.id/index.php/constitutionale

P-ISSN: 2723-2492

E-ISSN: $2745-9322$

\title{
Konsekuensi Pembentukan Peraturan Pemerintah Nomor 60 Tahun 2016 Tentang BNP Yang Tidak Memenuhi Kaidah Pembentukan Peraturan Perundang-Undangan
}

Consequences of the Formation of Government Regulation Number 60 of 2016 concerning Bnp Not Fulfilling the Rules of Establishing Prevailing Laws

Aryanto Sofyan

aryantosofyan44@gmail.com

\section{Lembaga Bantuan Hukum Bandar Lampung}

Submitted: Mar 30, 2020; Reviewed: Apr 20, 2020; Accepted: Mei 8, 2020

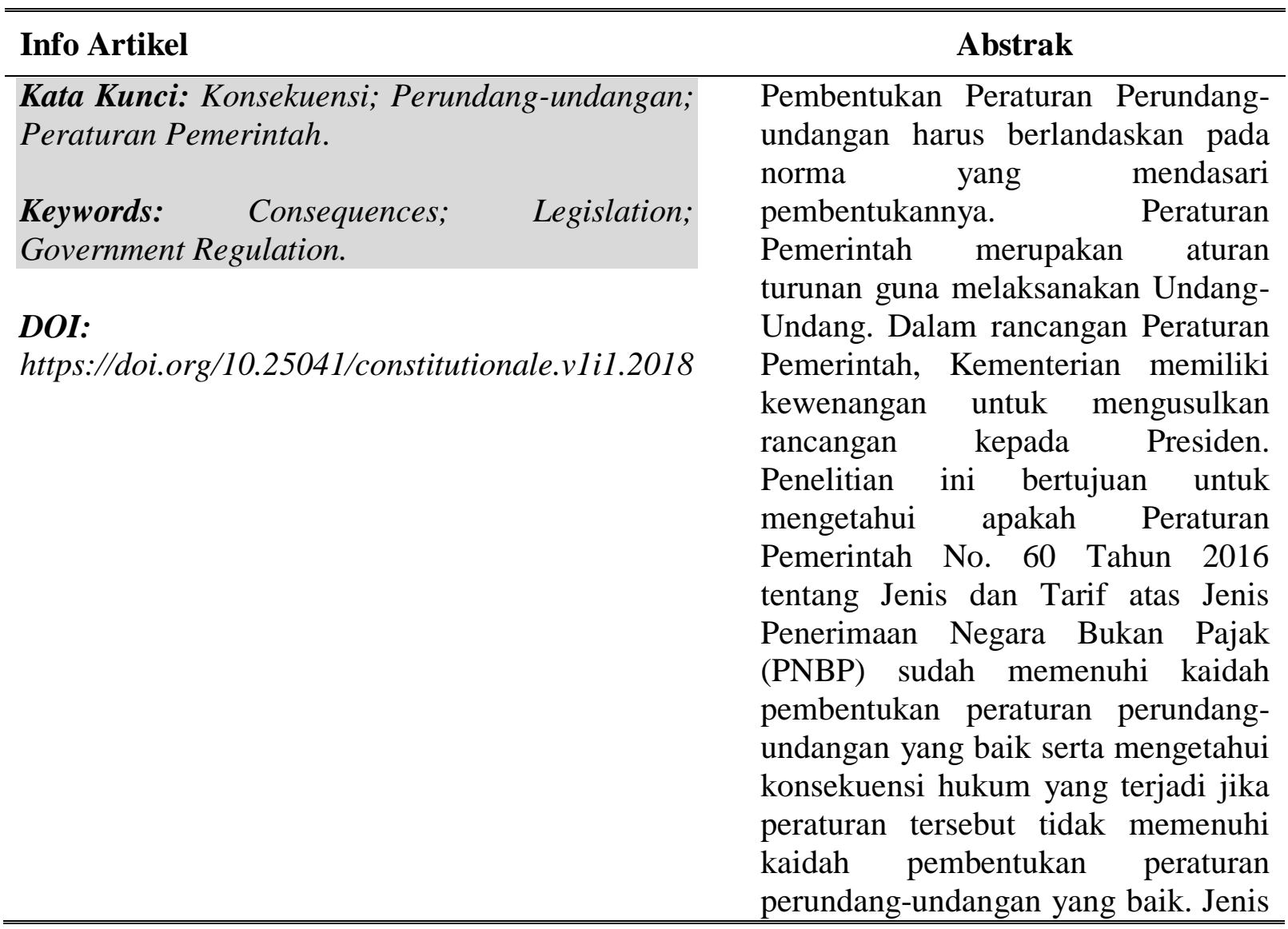




\begin{tabular}{|c|}
\hline $\begin{array}{l}\text { penelitian ini adalah penelitian } \\
\text { hukum yuridis normatif. Secara } \\
\text { normatif melakukan penelitian } \\
\text { dengan pengkajian sumber hukum } \\
\text { yang berkaitan dengan masalah yang } \\
\text { diangkat. Hasil penelitian } \\
\text { menunjukkan bahwa Peraturan } \\
\text { Pemerintah Nomor } 60 \text { Tahun } 2016 \\
\text { tentang Jenis dan Tarif atas Jenis } \\
\text { Penerimaan Negara Bukan Pajak } \\
\text { (PNBP) tidak memenuhi kaidah } \\
\text { pembentukan peraturan perundang- } \\
\text { undangan yang baik. }\end{array}$ \\
\hline $\begin{array}{l}\text { Abstract } \\
\text { The formation of laws and } \\
\text { regulations must be based on the } \\
\text { norms that underlie their formation. } \\
\text { Government regulations are } \\
\text { derivative rules for implementing } \\
\text { laws. In the draft Government } \\
\text { Regulation, the Ministry has the } \\
\text { authority to propose a draft to the } \\
\text { President. This study aims to } \\
\text { determine whether Government } \\
\text { Regulation no. } 60 \text { of } 2016 \text { concerning } \\
\text { Types and Rates of Types of Non-Tax } \\
\text { State Revenue (PNBP) has met the } \\
\text { principles of forming good laws and } \\
\text { regulations and knows the legal } \\
\text { consequences that occur if these } \\
\text { regulations do not meet the rules for } \\
\text { forming good laws and regulations. } \\
\text { This type of research is normative } \\
\text { juridical legal research. Normatively } \\
\text { doing research by assessing the } \\
\text { sources of law related to the issues } \\
\text { raised. The results of the study show } \\
\text { that Government Regulation Number } \\
\text { 60 of } 2016 \text { concerning Types and } \\
\text { Rates of Non-Tax State Revenue } \\
\text { (PNBP) does not meet the rules of } \\
\text { forming good laws and regulations. }\end{array}$ \\
\hline
\end{tabular}




\section{A. Pendahuluan}

Peraturan Pemerintah ditetapkan oleh Presiden ${ }^{1}$ sebagaimana ditentukan dalam UndangUndang Dasar Negara Republik Indonesia Tahun 1945 pada Pasal 5 ayat (2) yakni Presiden menetapkan Peraturan Pemerintah untuk menjalankan undang-undang sebagaimana mestinya. Materi muatan peraturan pemerintah pada Pasal 12 Undang-Undang Nomor 12 Tahun 2011 tentang Pembentukan Peraturan Perundang-Undangan berisi materi untuk menjalankan undang-undang sebagaimana mestinya. ${ }^{2}$ Rancangan peraturan pemerintah berasal dari kementerian atau lembaga pemerintah nonkementrian sesuai dengan bidang tugasnya. Dalam keadaan tertentu, kementerian atau lembaga pemerintahan non kementrian dapat mengajukan rancangan peraturan pemerintah diluar perencanaan penyusunan peraturan pemerintah yang dibuat berdasarkan kebutuhan undang-undang atau putusan Mahkamah Agung. ${ }^{3}$

Ketentuan lebih lanjut mengenai tata cara perencanaan penyusunan peraturan pemerintah diatur dengan peraturan presiden. ${ }^{4}$ Sebagai produk peraturan yang terbentuk dari lembaga eksekutif, Peraturan Pemerintah Nomor 60 Tahun 2016 tentang Jenis dan Tarif atas Jenis Penerimaan Negara Bukan Pajak (PNBP) adalah turunan dari Undang-Undang Nomor 20 tahun 1997 tentang Penerimaan Negara Bukan Pajak dan pengganti dari Peraturan Pemerintah Nomor 50 Tahun 2010 tentang Jenis dan Tarif atas Jenis Penerimaan Negara Bukan Pajak (PNBP) dan Peraturan Pemerintah Nomor 60 Tahun 2016 ini telah sah berlaku pada tanggal 6 januari 2017. ${ }^{5}$ Peraturan Pemerintah Nomor 60 Tahun 2016 tentang Jenis Dan Tarif Atas Jenis Penerimaan Negara Bukan Pajak (PNBP) terdapat kenaikan biaya Surat Tanda Nomor Kendaraan Bermotor (STNK) dan Buku Kepemilikan Kendaaraan Bermotor (BPKB) yang merupakan sumber dari Penerimaan Negara Bukan Pajak (PNBP) dan resmi berlaku mulai tanggal 6 Januari 2017. Hal ini mendapatkan respon dari Menteri Keuangan yang merasa tidak pernah mengusulkan melalui Kementerian Keuangan. Kapolri pun juga tidak tahu dan bukan usulan dari POLRI. Presiden pun mengaku itu terlalu mahal dan mempertanyakan karena dianggap naik tiga kali lipat. Hal ini tentunya menunjukan tidak adanya koordinasi yang baik. $^{6}$

Koordinator Advokasi dan Investigasi Forum Indonesia untuk Transparansi Anggaran (Fitra) Apung Widadi mengatakan, terjadinya lempar tanggung jawab perihal usulan kenaikan biaya pengurusan dokumen kendaraan tersebut mencerminkan tidak adanya koordinasi yang baik antara Kementerian Keuangan, Kepolisian, dan lembaga pemerintahan lainnya dalam menyusun peraturan ini. Bahkan, melalui pernyataannya, Presiden Joko Widodo (Jokowi) justru mempertanyakan kenaikan biaya pengurusan dokumen kendaraan tersebut yang mencapai 300 persen dari tarif awal. ${ }^{7}$ Permasalahan dalam Peraturan Pemerintah Nomor 60 Tahun 2016 yakni terdapatnya suatu disharmonisasi kewenangan antar lembaga negara ${ }^{8}$ yakni Presiden, Kementrian Keuangan, dan Kepolisian Republik Indonesia dalam pembuatan suatu

\footnotetext{
${ }^{1}$ Mohammad Roesli Daniel Susilo, "Konsepsi Kekuasaan Legislasi Presiden Dalam Undang-Undang Dasar 1945,” Mimbr Yustitia 2, no. 2 (2018): 159-73.

2 Insan Tajali Nur, "Memantapkan Landasan Hukum Formil Sebagai Alat Singkronisasi Dan Harmonisasi Peraturan Perundang - Undangan," Yuriska : Jurnal Ilmiah Hukum 10, no. 2 (2020): 158-74, https://doi.org/10.24903/yrs.v10i2.355.

${ }^{3}$ Radita Ajie, "Batasan Pilihan Kebijakan Pembentuk Undang-Undang (Open Legal Policy) Dalam Pembentukan Peraturan Perundang-Undangan Berdasarkan Tafsir Putusan Mahkamah Konstitusi,” Jurnal Legislasi Indonesia (Indonesian Journal of Legislation) 13, no. 2 (2016): 111-20.

${ }^{4}$ Armen Yasir, Hukum Perundang-Undangan(Bandar Lampung: PKKPU FH Unila), 2015,hlm 152-153

${ }^{5}$ M Taufiqurahman, "Peran Perancang Peraturan Perundang-Undangan Kementerian Hukum Dan Hak Asasi Manusia Dalam Pengawasan Produk Hukum Daerah Melalui Executive," Soumatera Law Review 2, no. 2 (2019): 270, https://doi.org/10.22216/soumlaw.v2i2.4341.

${ }^{6} \mathrm{http}: / /$ www.diskusihukum.com/2017/01/07/stnk-dan-bpkb-naik-kebijakan-presiden-sebagai-kepala-pemerintahan/ diakses pada 30 agustus 2017

${ }^{7} \mathrm{http}: / /$ katadata.co.id/berita/2017/01/05/heboh-kenaikan-biaya-stnk-pemerintah-dinilai-kurang-koordinasi diakses pada 30 agustus 2017

8 Shandi Patria Airlangga, "Hakikat Penguasa Dalam Negara Hukum Demokratis," Cepalo 3, no. 1 (2019): 1-10, https://doi.org/10.25041/cepalo.v3no1.1783.
} 
produk undang-undang dan peraturan pemerintah ini cacat prosedural. Maka dari itu perlu adanya suatu pengujian formil maupun pengujian materiil dalam peraturan pemerintah ini. Rumusan masalah dalam penelitian ini apakah Peraturan Pemerintah Nomor 60 Tahun 2016 tentang Jenis dan Tarif atas Jenis Penerimaan Negara Bukan Pajak (PNBP) sudah memenuhi kaidah pembentukan peraturan perundang-undangan yang baik. Pendekatan masalah yang digunakan yakni pendekatan perundang-undangan (statute approach) dan pendekatan konseptual (conceptual approach).

\section{B. Pembahasan}

1. Analisis Terhadap Asas-Asas Pembentukan Peraturan Perundang-Undangan Yang Baik Pada Peraturan Pemerintah Nomor 60 Tahun 2016 Tentang Jenis Dan Tarif Atas Jenis Penerimaan Negara Bukan Pajak (Pnbp)

Pembentukan undang-undang menyangkut empat bentuk kegiatan ${ }^{9}$ diantaranya prakarsa pembentukan undang-undang (legislative initiation), pembahasan rancangan undangundang(law-making process), persetujuan atas pengesehan rancangan undang-undang (law enactment approval) dan pemberian persetujuan pengikatan atau ratifikasi atas perjanjian atau persetujuan internasional dan dokumen-dokumen hukum yang mengikat lainnya (binding decision making on internasional law agreement and treaties or other legal binding documents). ${ }^{10}$ Undang-Undang Nomor 12 Tahun 2011 tentang Pembentukan Peraturan Perundang-Undangan dalam Pasal 5 mengatur pembentukan peraturan perundang-undangan dilakukan berdasarkan pada asas pembentukan peraturan perundang-undangan yang baik meliputi kejelasan tujuan, kelembagaan atau pejabat pembentuk yang tepat, kesesuaian antara jenis, hierarki, dan materi muatan, dapat dilaksanakan, kedayagunaan dan kehasilgunaan serta kejelasan rumusan dan keterbukaan. ${ }^{11}$

Pasal 7 Undang-Undang Nomor 12 Tahun 2011 tentang Pembentukan Peraturan PerundangUndangan menyebutkan.

1) Jenis dan hierarki Peraturan Perundang-undangan terdiri atas:

a. Undang-Undang Dasar Negara Republik Indonesia Tahun 1945;

b. KetetapanMajelis Permusyawaratan Rakyat;

c. Undang-Undang/Peraturan Pemerintah Pengganti Undang-Undang;

d. Peraturan Pemerintah;

e. Peraturan Presiden;

f. Peraturan Daerah Provinsi; dan

g. Peraturan Daerah Kabupaten/Kota. ${ }^{12}$

Peraturan pemerintah ditetapkan Presiden sebagaimana ditentukan dalam UUD 1945 pada Pasal 5 ayat (2) yakni Presiden menetapkan peraturan pemerintah untuk menjalankan undang-undang sebagaimana mestinya. ${ }^{13}$ Prakarsa penyusunan rancangan undang-undang dilingkungan pemerintah, peraturan pemerintah oleh menteri atau pimpinan lembaga

\footnotetext{
${ }^{9}$ Putera Astomo, "Pembentukan Undang-Undang Dalam Rangka Pembaharuan Hukum Nasional Di Era Demokrasi," Jurnal Konstitusi 11 (2014): 577-99.

10. Jimly asshiddiqie, Pengantar Ilmu Hukum Tata Negara, jilid II, sekretariat jendral mahkamah konstitusi republik Indonesia, Jakarta: 2006. Hlm. 34.

${ }^{11}$.Lihat pasal 5 UU no 12 tahun 2011 tentang Pembentukan Peraturan Perundang-undangan

12. Ibid. pasal 7.

13 Firman Manan, "Dewan Perwakilan Daerah Republik Indonesia Dalam Sistem Pemerintahan Republik Indonesia," CosmoGov 1, no. 1 (2017): 48-61, https://doi.org/10.24198/cosmogov.v1i1.11860.
} 
pemerintah non departemen sesuai dengan lingkup tugas dan tanggung jawabnya. ${ }^{14}$ Penjelasan tersebut sudah menjelaskan jika peraturan pemerintah dibuat oleh eksekutif, namun Peraturan Pemerintah Nomor 60 Tahun 2016 tentang Jenis dan Tarif atas Jenis Penerimaan Negara Bukan Pajak (PNBP) pada praktik nya tidak memperhatikan kelembagaan atau organ pembentuk yang tepat dikarenakan hal ini mendapatkan respon dari Menteri Keuangan yang merasa tidak pernah mengusulkan melalui Kementerian Keuangan. ${ }^{15}$ Hal ini tentunya menunjukan kesalahan dalam koordinasi. Kaidah pembentukan perundang-undangan yang baik dapat ditinjau dari asas-asas pembentukan peraturan perundang-undangan baik secara asas formil maupun asas materiil. ${ }^{16}$ Merujuk kepada Undang-Undang Nomor 12 Tahun 2011 tentang Pembentukan Peraturan Perundang-undangan pada Pasal 5 dalam membentuk peraturan perundang-undangan harus didasarkan pada asas pembentukan peraturan perundang-undangan yang baik (asas formil) diantaranya :

\section{Asas yang bersifat formil}

a. Asas tujuan yang Jelas

Tujuan dibentuknya Peraturan Pemerintah Nomor 60 Tahun 2016 tentang Jenis dan Tarif atas Jenis Penerimaan Negara Bukan Pajak (PNBP) terdapat pada konsideran yang menyatakan dalam rangka mengoptimalkan penerimaan negara bukan pajak guna menunjang pembangunan nasional, penerimaan negara bukan pajak pada Kepolisian Negara Republik Indonesia sebagai salah satu sumber penerimaan negara perlu dikelola dan dimanfaatkan untuk peningkatan pelayanan kepada masyarakat. Kepolisian Negara Republik Indonesia telah memiliki jenis dan tarif atas jenis penerimaan negara bukan pajak sebagaimana diatur dalam Peraturan Pemerintah Nomor 50 Tahun 2010 tentang Jenis dan Tarif atas Jenis Penerimaan Negara, bukan pajak yang berlaku pada Kepolisian Negara Republik Indonesia. Namun, dengan adanya jenis penerimaan bukan pajak yang baru dan penyesuaian tarif, perlu diatur kembali jenis dan tarif atas jenis penerimaan negara bukan pajak yang berlaku pada Kepolisian Negara Republik Indonesia dengan Pemerintah Pemerintah. ${ }^{17}$ Sebagaimana telah diurai dalam konsideran tersebut, tujuan dari dibentuknya Peraturan Pemerintah Nomor 60 Tahun 2016 tentang Jenis dan Tarif atas Jenis Penerimaan Negara Bukan Pajak (PNBP) jika memang tujuan dari terciptanya peraturan pemerintah ini sebagai salah satu sumber penerimaan negara perlu dikelola dan dimanfaatkan untuk peningkatan pelayanan kepada masyarakat maka pemerintah sangatlah keliru karena pemerintah tidak memperhatikan reaksi yang terjadi pada masyarakat ketika peraturan pemerintah ini disahkan. Terdapatnya persepsi yang salah dari pemerintah dengan menaikan tarif hingga 2-3 kali lipat, kenaikan yang signifikan ini sangat memberatkan masyarakat dan belum tentu dengan dinaikan nya tarif PNBP ini akan berdampak dalam meningkatnya pelayanan pada masyarakat.

b. Asas kelembagaan atau organ pembentuk yang tepat

Peraturan Pemerintah ditetapkan Presiden sebagaimana diatur dalam UUD 1945 pada pasal 5 ayat (2) yakni Presiden menetapkan Peraturan Pemerintah untuk menjalankan undang-

\footnotetext{
${ }^{14}$ Rahayu Prasetianingsih, "Menakar Kekuasaan Presiden Dalam Pembentukan Peraturan Perundang-Undangan Menurut Undang-Undang Dasar 1945," PADJADJARAN Jurnal Ilmu Hukum (Journal of Law), 2017, https://doi.org/10.22304/pjih.v4n2.a3.

${ }^{15}$ Nanang Suparman, "Pengaruh Implementasi Kebijakan Audit Penerimaan Negara Bukan Pajak (Pnbp) Terhadap Kinerja Auditor Pada Pusat Pengembangan Dan Penataran Guru Ipa Kota Bandung," Jurnal Akuntansi Dan Perpajakan 3, no. 1 (2017): 1-12, https://doi.org/10.26905/ap.v3i1.1326.

16 Tubagus Muhammad Nasarudin, "Asas Dan Norma Hukum Administrasi Negara Dalam Pembuatan Instrumen Pemerintahan," Jurnal Hukum Novelty 7, no. 2 (2016): 139-54, https://doi.org/10.26555/novelty.v7i2.a5463.

${ }^{17}$ Isi Konsideran dalam Peraturan Pemerintah No. 60 Tahun 2016 tentang Jenis dan Tarif atas Jenis Penerimaan Negara Bukan Pajak (PNBP)
} 
undang sebagaimana mestinya. ${ }^{18}$ Prakarsa penyusunan rancangan undang-undang dilingkungan pemerintah, peraturan pemerintah, menteri atau pimpinan lembaga pemerintah non departemen sesuai dengan lingkup tugas dan tanggung jawabnya. Pemrakarsa dalam menyusun rancangan undang-undang terlebih dahulu menyusun naskah akademik mengenai materi yang akan diatur dalam rancangan undang-undang. Penyusunan rancangan undangundang dilakukan berdasarkan Program Legislasi Nasional (Prolegnas). ${ }^{19}$ Perencanaan penyusunan peraturan pemerintah dikoordinasikan oleh menteri yang menyelenggarakan urusan pemerintahan dibidang hukum. Rancangan peraturan pemerintah berasal dari kementrian atau lembaga pemerintah non kementrian sesuai dengan bidang tugasnya. ${ }^{20}$ Penjelasan tersebut menjelaskan jika peraturan pemerintah dibuat oleh pemerintah, namun Peraturan Pemerintah Nomor 60 Tahun 2016 tentang Jenis dan Tarif atas Jenis Penerimaan Negara Bukan Pajak (PNBP) pada praktik nya tidak memperhatikan asas kelembagaan atau organ pembentuk yang tepat dikarenakan hal ini mendapatkan respon dari Menteri Keuangan yang merasa tidak pernah mengusulkan melalui Kementerian Keuangan. Kapolri pun juga tidak tahu dan bukan usulan dari POLRI. Presiden pun mengaku itu terlalu mahal dan mempertanyakan karena dianggap naik tiga kali lipat. Hal ini tentunya menunjukan tidak adanya koordinasi yang baik. ${ }^{21}$

Koordinator Advokasi dan Investigasi Forum Indonesia untuk Transparansi Anggaran (Fitra) Apung Widadi mengatakan, adanya saling lempar tanggung jawab perihal usulan kenaikan biaya pengurusan dokumen kendaraan tersebut mencerminkan tidak adanya koordinasi yang baik antara Kementerian Keuangan, Kepolisian, dan lembaga pemerintahan lainnya dalam menyusun peraturan ini. Bahkan, Presiden Joko Widodo mempertanyakan kenaikan biaya pengurusan dokumen kendaraan tersebut yang mencapai 300 persen dari tarif awal. ${ }^{22}$ Tidak adanya koordinasi antara pemerintah merupakan suatu kesalahan dari pemerintah dalam hal ini eksekutif yang mempunyai wewenang dalam pembentukan peraturan pemerintah sangatlah jelas dalam pembentukan peraturan pemerintah ini tidak memerhatikan asas kelembagaan atau organ pembentuk yang tepat, seolah-olah Peraturan Pemerintah Nomor 60 Tahun 2016 tentang Jenis dan Tarif atas Jenis Penerimaan Negara Bukan Pajak (PNBP) adalah peraturan pemerintah yang illegal karena isu yang beredar di media massa tidak ada yang tahu siapa yang membentuknya.

c. Asas kesesuaian antara jenis dan materi muatan

Peraturan pemerintah adalah peraturan yang dibentuk sebagai peraturan yang menjalankan undang-undang atau peraturan yang dibentuk guna ketentuan dalam undangundang dapat berjalan. ${ }^{23}$ Peraturan pemerintah dibentuk Presiden yang berfungsi untuk menjalankan undang-undang. Dengan demikian, materi muatan yang diatur dalam peraturan pemerintah tidak boleh menyimpang dari materi yang diatur dalam undang-undang yang bersangkutan. sesuai ketentuan pemerintah berisi materi untuk menjalankannya undangundang sebagaimana mestinya. ${ }^{24}$ Sebagai produk Undang-Undang yang terbentuk dari lembaga eksekutif Peraturan Pemerintah Nomor 60 Tahun 2016 tentang Jenis dan Tarif atas Jenis Penerimaan Negara Bukan Pajak (PNBP) adalah turunan dari Undang-Undang Nomor

\footnotetext{
${ }^{18}$ Hezky Fernando Pitoy, "Mekanisme Checks And Balances Antara Presiden Dan DPR Dalam Sistem Presidensial Di Indonesia," Lex et Societatis 11, no. 5 (2014): 28-38.

${ }^{19}$ Yuliandri, Loc. Cit . Hlm 95

20 .Armen Yasir., Loc. Cit., hlm 152-153

${ }^{21}$ http://www.diskusihukum.com/2017/01/07/stnk-dan-bpkb-naik-kebijakan-presiden-sebagai-kepala-pemerintahan/ diakses pada 30 agustus 2017

${ }^{22} \mathrm{http} / / /$ katadata.co.id/berita/2017/01/05/heboh-kenaikan-biaya-stnk-pemerintah-dinilai-kurang-koordinasi diakses pada 30 agustus 2017

23 Retno - Saraswati, "Problematika Hukum Undang-Undang No.12 Tahun 2011 Tentang Pembentukan Peraturan Perundang-Undangan," Yustisia Jurnal Hukum 2, no. 3 (2013): 97-103, https://doi.org/10.20961/yustisia.v2i3.10164.

${ }^{24}$ Armen Yasir., Loc. Cit., hlm 108
} 
20 Tahun 1997 tentang Penerimaan Negara bukan pajak. Dan pengganti dari Peraturan Pemerintah Nomor 50 Tahun 2010 tentang tentang Jenis dan Tarif atas Jenis Penerimaan Negara Bukan Pajak (PNBP), oleh karena itu materi muatan Peraturan Pemerintah Nomor 60 Tahun 2016 tentang Jenis dan Tarif atas Jenis Penerimaan Negara Bukan Pajak ini tidak boleh bertentangan dengan Undang-Undang Nomor 20 Tahun 1997 tentang Penerimaan Negara Bukan Pajak.

Materi muatan pada peraturan pemerintah ini tentang kenaikan Tarif atas Jenis Penerimaan Negara Bukan Pajak yang dirasa sangat memberatkan masyarakat yang dimana terdapat kenaikan biaya dua sampai tiga kali lipat untuk urusan STNK dan BPKB, materi muatan peraturan pemerintah ini sangatlah bertentangan dengan Undang-Undang Nomor 20 Tahun 1997 tentang Penerimaan Negara Bukan Pajak karena dalam Pasal 3 ayat 1 yang berbunyi "Tarif atas jenis Penerimaan Negara Bukan Pajak ditetapkan dengan memperhatikan dampak pengenaan terhadap masyarakat dan kegiatan usahanya, biaya penyelenggaraan kegiatan pemerintah sehubungan dengan jenis Penerimaan Negara Bukan Pajak yang bersangkutan, dan aspek keadilan dalam pengenaan beban kepada masyarakat.. ${ }^{25}$ Dalam peraturan pemerintah ini bertentangan dengan undang-undang diatasnya yakni UndangUndang Nomor 20 Tahun 1997 tentang Penerimaan Negara Bukan Pajak dan tidak memerhatikan asas kesesuaian jenis dan materi muatan.

d. Asas Dapat Dilaksanakan

Pembentukan Peraturan Pemerintah Nomor 60 Tahun 2016 tentang Jenis dan Tarif Atas Jenis Penerimaan Negara Bukan Pajak ini tidak dapat dilaksanakan dikarenakan secara yuridis peraturan pemerintah ini bertentangan dengan Undang-Undang Nomor 20 Tahun 1997 tentang Penerimaan Negara Bukan Pajak karena kenaikan tarif yang ada pada materi muatan peratruan pemerintah ini tidak memperhatikan Pasal 3 ayat 1 Undang-Undang Nomor 20 tahun 1997 tentang Penerimaan Negara Bukan Pajak yang menyatakan tarif atas jenis penerimaan negara bukan pajak ditetapkan dengan memperhatikan dampak pengenaan terhadap masyarakat dan kegiatan usahanya, biaya penyelenggaraan kegiatan pemerintah sehubungan dengan jenis penerimaan negara bukan pajak yang bersangkutan dan aspek keadilan dalam pengenaan beban kepada masyarakat. Secara sosiologis, peraturan pemerintah ini tidak memperhatikan keadaan sosial di masyarakat dengan menaikan biaya sampai tiga kali lipat untuk urusan STNK dan BPKB pastinya jika tetap dilaksanakan peraturan pemerintah ini akan menimbulkan gejolak-gejolak di masyarakat.

e. Asas Kedayagunaan dan Kehasilgunaan

Asas kedayagunaan dan kehasilgunaan setiap peraturan perundang-undangan dibutuhkan dan bermanfaat dalam mengatur kehidupan bermasyarakat, berbangsa, dan bernegara. Jika dilhat dari isi konsideran Peraturan Pemerintah Nomor 60 Tahun 2016 tentang Jenis dan Tarif atas Jenis Penerimaan Negara Bukan Pajak dibuat sebagai salah satu sumber penerimaan negara perlu dikelola dan dimanfaatkan untuk peningkatan pelayanan kepada masyarakat. Akan tetapi isi materi mauatan peraturan pemerintah ini memberatkan masyarakat dengan kenaikan hampir tiga kali lipat dalam tarif untuk urusan STNK dan BPKB sehingga dapat dipastikan bahwa kenaikan PNPB ini tidak terlebih dahulu dilakukan evaluasi dan uji publik sehingga tidak memerhatikan nilai daya guna serta kehasilgunaan dari terbentuknya peraturan pemerintah ini.

f. Asas Kejelasan Rumusan

Pelaksanan dalam Pasal 8 ayat (1) Peraturan Presiden Nomor 1 Tahun 2007 tentang Pengesahan, Pengundangan, dan Penyebarluasan Peraturan Perundang-undangan merumuskan, Presiden menetapkan rancangan peraturan pemerintah pengganti undangundang, rancangan peraturan pemerintah dan rancangan peraturan presiden yang telah disusun

\footnotetext{
${ }^{25}$ Lihat pasal 3 ayat 1 dalam UU No. 20 Tahun 1997 tentang penerimaan Negara bukan pajak
} 
berdasarkan ketentuan mengenai tata cara mempersiapkan rancangan undang-undang, rancangan peraturan pemerintah pengganti undang-undang, rancangan peraturan pemerintah dan rancangan peraturan presiden. Untuk melaksanakan ketentuan tersebut, Menteri Sekretaris Negara melakukan penyiapan naskah rancangan peraturan pemerintah, kemudian presiden menetapkan peraturan pemerintah dengan membubuhkan tanda tangan. Kemudian, Menteri Sekretaris Negara membubuhkan nomor dan tahun pada naskah Peraturan Pemerintah untuk disampaikan kepada menteri untuk diundangkan. ${ }^{26}$ Akan tetapi dalam proses pembentukan Peraturan Pemerintah Nomor 60 Tahun 2016 tentang Jenis dan Tarif atas Jenis Penerimaan Negara Bukan Pajak menurut Transparansi Anggaran (FITRA) Yenny Sucipto menilai langkah pemerintah menambah pemasukan negara dengan menerbitkan Peraturan Pemerintah Nomor 60 Tahun 2016 kurang tepat.

Pasalnya, kata Yenny, Peraturan Pemerintah Nomor 60 Tahun 2016 terkesan illegal karena tidak jelas siapa yang bertanggung jawab dalam penyusunannya, terlihat dari sejumlah pernyataan Menteri, Kepolisian maupun Presiden yang tidak mengetahui usulan kenaikan melalui peraturan pemerintah tersebut. ${ }^{27}$ Sehingga, peraturan pemerintah ini tidak memenuhi persyaratan teknis dalam penyusunan peraturan perundang-undangan, ${ }^{28}$ karena sudah jelas dalam Peraturan Presiden Nomor 1 Tahun 2007 tentang Pengesahan, Pengundangan dan Penyebarluasan Peraturan Perundang-Undangan menyatakan Presiden menetapkan peraturan pemerintah dan menteri terkait dalam hal ini menteri keuangan yang mengusulkan peraturan pemerintah ini tetapi pada saat terjadi kegaduhan karena disahkan nya peraturan pemerintah ini, semua pihak yang terkait dalam pembentukan peraturan pemerintah ini, Presiden maupun Menteri Keuangan membuat pernyataan di media massa seolah-olah mereka tidak tahumenahu mengapa peraturan pemerintah ini terbentuk, apabila mereka tidak mengetahui maka sudah jelas peraturan pemerintah ini tidak memiliki kejelasan rumusan.

g. Asas keterbukaan

Adanya saling lempar tanggung jawab perihal usulan kenaikan biaya pengurusan dokumen kendaraan tersebut mencerminkan tidak adanya koordinasi yang baik antara Kementerian Keuangan, Kepolisian, dan lembaga pemerintahan lainnya dalam menyusun peraturan ini. Pasal 6 ayat (1) UU No. 12 Tahun 2011 tentang Pembentukan Peraturan Perundang-undangan memberi penjelasan dalam membuat Materi muatan Peraturan Perundang-undangan harus mencerminkan asas:

\section{Asas yang bersifat materill}

a. Asas Pengayoman

Asas pengayoman dalah bahwa setiap Materi Muatan Peraturan Perundang- undangan harus berfungsi memberikan pelindungan untuk menciptakan ketentraman masyarakat. Materi muatan Peraturan Pemerintah Nomor 60 Tahun 2016 tentang Jenis dan Tarif atas Jenis Penerimaan Negara Bukan Pajak ialah tentang kenaikan tarif Penerimaan Negara Bukan Pajak yang dimana kenaikan tarif yang signifikan hingga dua sampai tiga kali lipat pastinya akan menimbulkan kekhawatiran di masyarakat dan juga akan memberatkan masyarakat Berikut Daftar Tarif Baru untuk kendaraan roda empat, STNK baru dari Rp50 ribu naik Rp200 Ribu. Perpanjangan STNK dari Rp50 Ribu naik Rp200 Ribu berlaku per lima tahun. Pengesahan STNK Rp50 ribu per tahun. Kemudian, STCKR dari Rp25 ribu naik menjadi Rp50 ribu, BPKB baru dari Rp100 ribu naik menjadi Rp375 ribu, BPKB Ganti Pemilik dari Rp100 ribu

\footnotetext{
${ }^{26}$ Lihat pasal 8 ayat (1), (2), dan (3) Peraturan Presiden No. 1 Tahun 2007 tentang Pengesahan, Pengundangan, dan Penyebarluasan Peraturan Perundang-undangan.

http://kanalhukum.id/liputan/tanpa-kajian-akademik-pp-kenaikan-pnbp-kendaraan-bermotor-bisa-digugat-kepengadilan/854 diakses pada 20 desember 2017

${ }^{28}$ Zaid Afif, "Pembentukan Peraturan Perundang-Undangan Berdasarkan Pancasila Dan Undang-Undang Dasar Negara Kesatuan Republik Indonesia,” Jurnal Dialog 7, no. 9 (2018).
} 
naik Rp375 Ribu dan Mutasi dari Rp75 Ribu naik menjadi Rp250 ribu. sedangkan bagi kendaraan roda dua yakni STNK Baru dari Rp50 Ribu naik menjadi Rp100 ribu, perpajangan STNK dulu Rp50 ribu naik menjadi Rp100 ribu per lima tahun. Selanjutnya, pengesahan STNK Rp25 ribu per tahun. hanya STCK tidak Selanjutnya, BPKB baru dari Rp80 ribu naik menjadi Rp225 ribu, ganti pemilik BPKB dari semula Rp80 ribu naik menjadi Rp225 ribu, sementara untuk mutasi kendaraan roda dua dari Rp75 ribu naik menjadi Rp150 ribu. Artinya dengan kenaikan ini pemerintah tidak memberikan perlindungan kepada masyarakat kecil yang merasa keberatan atas kenaikan harga PNPB ini.

b. Asas Kemanusiaan

Asas kemanusiaan merupakan materi muatan peraturan perundang-undangan harus mencerminkan pelindungan dan penghormatan hak asasi manusia serta harkat dan martabat setiap warga negara dan penduduk Indonesia secara proporsional. Materi muatan dalam Peraturan Pemerintah Nomor 60 Tahun 2016 tentang Jenis dan Tarif atas Jenis Penerimaan Negara Bukan Pajak tentang kenaikan tarif Penerimaan Negara Bukan Pajak dimana kenaikan tarif yang signifikan hingga dua sampai tiga kali lipat. Penerimaan negara bukan pajak merupakan seluruh penerimaan pemerintah pusat yang tidak berasal dari penerimaan perpajakan, penerimaan negara bukan pajak wajib dibayar oleh pribadi yang ditentukan untuk melakukan kewajiban membayar menurut peraturan perundang-undangan yang berlaku. Dengan adanya kewajiban membayar ini maka perorangan harus menanggung beban yang besar hingga dua sampai tiga kali lipat yang pastinya tidak memerhatikan keadaan masyarakat Indonesia. Terlihat jika pemerintah tidak melihat sisi kemanusiaan dalam pembentukan materi muatan peraturan pemerintah ini.

c. Asas Keadilan

Asas keadilan merupakan materi muatan peraturan perundang-undangan harus mencerminkan keadilan secara proporsional bagi setiap warga negara. Keadilan menurut kamus besar bahasa Indonesia yakni nominal (kata benda) sifat (perbuatan, perlakuan, dan sebagainya) yang adil mempertahankan hak dan keadilan nya. Pemerintah menciptakan keadilan bagi masyarakat. Materi muatan Peraturan Pemerintah Nomor 60 Tahun 2016 tentang Jenis dan Tarif atas Jenis Penerimaan Negara Bukan Pajak ini tidak mencerminkan keadilan di masyarakat dikarenakan kesewenang-wenangan pemerintah dalam menaikan tarif hingga dua sampai tiga kali lipat. Pemerintah dalam membuat peraturan ini tidak mencerminkan keadilan yang proporsional bagi setiap warga Negara Indonesia karena tidak semua masyarakat mampu membayar tarif STNK, SIM, maupun BPKB yang naik hingga tiga kali lipat dari tarif sebelumnya.

d. Asas Kesamaan Kedudukan dalam Hukum dan Pemerintahan

Asas kesamaan kedudukan dalam hukum dan pemerintahan merupakan materi muatan peraturan perundang-undangan yang tidak boleh memuat hal yang bersifat membedakan berdasarkan agama, suku, ras, golongan, gender, atau status sosial. Materi muatan Peraturan Pemerintah Nomor 60 Tahun 2016 tentang Jenis dan Tarif atas Jenis Penerimaan Negara Bukan Pajak ini memang tidak memuat hal-hal yang bersifat membedakan latar belakang, akan tetapi kenaikan yang signifikan tidak relavan dengan keadaan ekonomi di masyarakat Indonesia karena disetiap wilayah Indonesia berbeda-beda keadaan ekonominya dan rata-rata masyarakat Indonesia masih tertinggal perekonomian nya.

e. Asas Ketertiban dan Kepastian Hukum

Asas ketertiban dan kepastian hukum merupakan materi muatan peraturan perundangundangan harus dapat mewujudkan ketertiban dalam masyarakat melalui jaminan kepastian 
hukum. ${ }^{29}$ Materi muatan Peraturan Pemerintah Nomor 60 Tahun 2016 tentang Jenis dan Tarif atas Jenis Penerimaan Negara Bukan Pajak tentang kenaikan tarif penerimaan Negara bukan pajak yang tarifnya naik sampai dua hingga tiga kali lipat dan tujuan nya untuk memperbaiki pelayanan di masyarakat, akan tetapi dengan kenaikan yang signifikan ini pasti akan menimbulkan kegaduhan di masyarakat dan dapat mengganggu ketertiban masyarakat dalam membayar tarif yang baru ini, dan masyarakat pasti akan terbebani dengan disahkan peraturan pemerintah ini.

f. Asas Keseimbangan, Keserasian, dan Keselarasan

Asas keseimbangan, keserasian, dan keselarasan merupakan materi muatan peraturan perundang-undangan yang harus mencerminkan keseimbangan, keserasian, dan keselarasan, antara kepentingan individu, masyarakat serta kepentingan bangsa dan negara. ${ }^{30}$ Materi muatan Peraturan Pemerintah Nomor 60 Tahun 2016 tentang Jenis dan Tarif atas Jenis Penerimaan Negara Bukan Pajak tersebut tidak memerhatikan keseimbangan, keserasian, dan keselarasan dikarenakan dengan kenaikan tarif hingga dua sampai tiga kali lipat dari tarif terdahulu hanya menguntungkan kepentingan pihak pemerintah dan pemerintah tidak memerhatikan apa yang terjadi di masyarakat jika peraturan pemerintah ini disahkan di masyarakat.

Masyarakat pastinya akan terbebani dengan kenaikan tersebut. Bila dicermati dalam peraturan tersebut terhadap asas-asas pembentukan peraturan perundang-undangan yang Baik dan asas-asas materi muatan peraturan perundang-undangan yang baik, dapat disimpulkan bahwa peraturan tersebut tidak memenuhi kaidah pembentukan peraturan perundangundangan yang baik. Jika peraturan pemerintah ini tidak memenuhi kaidah pembentukan peraturan perundang-undangan yang baik, dengan dasar inilah peraturan pemerintah ini dapat dilakukan judicial review ke Mahkamah Agung dan menghasilkan Putusan Mahkamah Agung No. 12/P HUM/2017 yang memutuskan Mengabulkan permohonan keberatan hak uji materiil dari Pemohon: MOH. NOVAL IBROHIM SALIM, S.H., M.H. untuk sebagian; Menyatakan Lampiran Lampiran Nomor E angka 1 dan 2 Peraturan Pemerintah Nomor 60 Tahun 2016 tentang Jenis dan Tarif atas Jenis Penerimaan Negara Bukan Pajak yang Berlaku pada Kepolisian Negara Republik Indonesia, bertentangan dengan peraturan perundang-undangan yang lebih tinggi, yaitu Pasal 73 ayat (5) Undang-Undang Nomor 30 Tahun 2014 tentang Administrasi Pemerintahan dan karenanya tidak sah dan tidak berlaku umum; Memerintahkan kepada Presiden Republik Indonesia untuk mencabut Lampiran Nomor E angka 1 dan 2 Peraturan Pemerintah Nomor 60 Tahun 2016 tentang Jenis dan Tarif atas Jenis Penerimaan Negara Bukan Pajak yang Berlaku pada Kepolisian Negara Republik Indonesia.

\section{Kesimpulan}

Berdasarkan penelitian yang telah dilakukan, penulis menyimpulkan jika peraturan Pemerintah Nomor 60 Tahun 2016 tentang Jenis dan Tarif atas Jenis Penerimaan Negara Bukan Pajak (PNBP) tidak memenuhi kaidah pembentukan peraturan perundang-undangan yang baik karena dalam proses pembentukannya tidak mengacu pada asas-asas pembentukan peraturan perundang-undangan yang baik yakni ini tidak memerhatikan asas-asas pembentukan (asas formil) dan asas materi muatan (materiil). Peraturan Pemerintah ini dapat di uji oleh Mahkamah Agung melalui proses pengujian undang-undang/ judicial review. Dikarenakan Peraturan Pemerintah Nomor 60 Tahun 2016 tentang Jenis dan Tarif atas Jenis Penerimaan Negara Bukan Pajak (PNBP) ini tidak sesuai dengan aspek formil dan aspek

\footnotetext{
29 Ratnia Solihah and Siti Witianti, "Pelaksanaan Fungsi Legislasi Dewan Perwakilan Rakyat Pasca Pemilu 2014: Permasalahan Dan Upaya Mengatasinya," CosmoGov 2, $\quad$ no. 2 (2016): 291-307, https://doi.org/10.24198/cosmogov.v2i2.10010.

30 Sapto Budoyo, "Konsep Langkah Sistemik Harmonisasi Hukum Dalam Pembentukan Peraturan Perundang-Undangan," Jurnal Ilmiah CIVIS 4 (2014): 641.
} 
materiil pembentukan peraturan perundang-undangan yang baik namun tetap dilaksanakan akan membebani masyarakat oleh karena itu pemerintah harus mencabut Peraturan Pemerintah Nomor 60 Tahun 2016 tentang Jenis dan Tarif atas Jenis Penerimaan Negara Bukan Pajak (PNBP).

\section{Daftar Pustaka}

A. Buku

Asshiddiqie, Jimly, Hukum Acara Pengujian Undang-Undang, (Jakarta: Sinar Grafika, 2012).

Asshiddiqie, Jimly, Pengantar Ilmu Hukum Tata Negara, (Jakarta: Sinar Grafika, 2006).

Asshiddiqie, Jimly, Pengantar Ilmu Hukum Tata Negara, Jilid II, (Jakarta; Sekretariat Jendral Mahkamah Konstitusi Republik Indonesia, 2006).

Doludjawa, Linus, Buku Pegangan Perancangan Peraturan Perundang-undangan, Jakarta: Direktorat Jendral Peraturan Perundang-undangan, DepartemenHukum dan Hak Asasi Manusia RI, 2005.

Hadikusuma, Hilman, Metode Pembuatan Kertas Kerja atau Skripsi Ilmu Hukum, (Mandar Maju: Bandung 1995).

Indrati, Maria Farida Ilmu Perundang Undangan, (Yogyakarta: Kanisius, 1998).

Kansil, C.S.T Hukum Tata Pemerintahah Indonesia, (Jakarta Timur: Ghalia Indonesia, 1985).

Mahfud Md, Moh, Konstitusi Dan Hukum Dalam Kontroversi isu (Depok: Rajagrafindo, 2012).

Mahmud Marzuki, Peter, Penelitian Hukum Normatif, (Jakarta: Kencana Prenada Media Group, 2010).

Poerwardarminta, Kamus Besar Bahasa Indonesia, (Jakarta: Balai Pustaka, 2001).

Soehino, Hukum Tata Negara Teknik Perundang-Undangan,(Yogyakarta:Liberty,1981).

Soemantri, R. Sri, Hak Uji Material Diindonesia,(Bandung:Alumni, 1997).

Soekamto, Soerjono, Pengantar Penelitian Hukum, (Jakarta: UI press, 1996).

Wahjono, Padmo, Masalah Ketatanegaraan Indonesia Dewasa Ini, (Jakarta: Ghalia Indonesia, 1984).

Yasir, Armen, Hukum Perundang-Undangan (Bandar Lampung: PKKPU FH Unila 2015).

Yuliandri, Asas-Asas Pembentukan Peraturan Perundang-Undangan Yang Baik, (Jakarta: Raja Grafindo, 2010).

B. Jurnal

Afif, Zaid. "Pembentukan Peraturan Perundang-Undangan Berdasarkan Pancasila Dan UndangUndang Dasar Negara Kesatuan Republik Indonesia.” Jurnal Dialog 7, no. 9, 2018.

Airlangga, Shandi Patria. "Hakikat Penguasa Dalam Negara Hukum Demokratis." Cepalo 3, no. 1, 2019: 1-10. https://doi.org/10.25041/cepalo.v3no1.1783.

Astomo, Putera. "Pembentukan Undang-Undang Dalam Rangka Pembaharuan Hukum Nasional Di Era Demokrasi." Jurnal Konstitusi 11, 2014: 577-99.

Attamimi, A. Hmmid S, Hukum tentang Peraturan Perundang-Undangan dan Peraturan Kebijakan, (Jakarta: FHUI, 1993).

Daniel Susilo, Mohammad Roesli. "Konsepsi Kekuasaan Legislasi Presiden Dalam UndangUndang Dasar 1945." Mimbr Yustitia 2, no. 2, 2018: 159-73.

Djani, Luky, Efektifitas Biaya dalam Pembentukan Legislasi, Jurnal Hukum Jentera Pusat Studi Hukum \& Kebijakan (PSHK), Jakarta, Edisi 10-Tahun III,2005.

Manan, Firman. "Dewan Perwakilan Daerah Republik Indonesia Dalam Sistem Pemerintahan Republik Indonesia." CosmoGov 1, no. 1, 2017: 48-61. https://doi.org/10.24198/cosmogov.v1i1.11860.

Nasarudin, Tubagus Muhammad. "Asas Dan Norma Hukum Administrasi Negara Dalam Pembuatan Instrumen Pemerintahan." Jurnal Hukum Novelty 7, no. 2, 2016: 139-54. https://doi.org/10.26555/novelty.v7i2.a5463. 
Nur, Insan Tajali. "Memantapkan Landasan Hukum Formil Sebagai Alat Singkronisasi Dan Harmonisasi Peraturan Perundang - Undangan." Yuriska: Jurnal Ilmiah Hukum 10, no. 2, 2020: 158-74. https://doi.org/10.24903/yrs.v10i2.355.

Pitoy, Hezky Fernando. "Mekanisme Checks And Balances Antara Presiden Dan DPR Dalam Sistem Presidensial Di Indonesia." Lex et Societatis 11, no. 5, 2014: 28-38.

Prasetianingsih, Rahayu. "Menakar Kekuasaan Presiden Dalam Pembentukan Peraturan Perundang-Undangan Menurut Undang-Undang Dasar 1945." PADJADJARAN Jurnal Ilmu Hukum (Journal of Law), 2017. https://doi.org/10.22304/pjih.v4n2.a3.

Radita Ajie. "Batasan Pilihan Kebijakan Pembentuk Undang-Undang (Open Legal Policy) Dalam Pembentukan Peraturan Perundang-Undangan Berdasarkan Tafsir Putusan Mahkamah Konstitusi." Jurnal Legislasi Indonesia (Indonesian Journal of Legislation) 13, no. 2, 2016 : 111-20.

Sapto Budoyo. "Konsep Langkah Sistemik Harmonisasi Hukum Dalam Pembentukan Peraturan Perundang-Undangan." Jurnal Ilmiah CIVIS 4, 2014: 641.

Saraswati, Retno. "Problematika Hukum Undang-Undang No.12 Tahun 2011 Tentang Pembentukan Peraturan Perundang-Undangan.” Yustisia Jurnal Hukum 2, no. 3, 2013: $97-$ 103. https://doi.org/10.20961/yustisia.v2i3.10164.

Solihah, Ratnia, and Siti Witianti. "Pelaksanaan Fungsi Legislasi Dewan Perwakilan Rakyat Pasca Pemilu 2014: Permasalahan Dan Upaya Mengatasinya." CosmoGov 2, no. 2, 2016: 291-307. https://doi.org/10.24198/cosmogov.v2i2.10010.

Suparman, Nanang. "Pengaruh Implementasi Kebijakan Audit Penerimaan Negara Bukan Pajak (Pnbp) Terhadap Kinerja Auditor Pada Pusat Pengembangan Dan Penataran Guru Ipa Kota Bandung." Jurnal Akuntansi Dan Perpajakan 3, no. 1, 2017: 1-12. https://doi.org/10.26905/ap.v3i1.1326.

Taufiqurahman, M. "Peran Perancang Peraturan Perundang-Undangan Kementerian Hukum Dan Hak Asasi Manusia Dalam Pengawasan Produk Hukum Daerah Melalui Executive." Soumatera Law Review 2, no. 2, 2019: 270. https://doi.org/10.22216/soumlaw.v2i2.4341. 